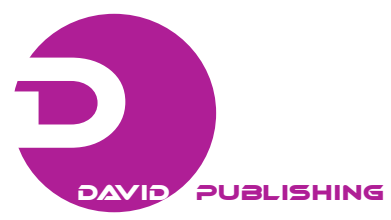

\title{
Economic Value of Crop Productivity Biodiversity in Ijebu Ode Agricultural Zone of Ogun State, Nigeria
}

\author{
Ayinde Alani Ezekiela, Igbekele Amos Ajibefun', Taiwo Nuraeni Akinnirana, Folayimi \\ Ogunwole-Olapade
}

\begin{abstract}
Biological diversity involves genetic, species, and ecosystem diversity. Genetic diversity denotes the variation within species in the functional units of heredity present in any plant or animal, microbial or other origin of living things. Species diversity encompasses the variety of species-whether wild or domesticated, within a geographical area. This study assesses the economic value of crop productivity biodiversity in Ijebu Ode agricultural zone of Ogun State. The authors proposed a dynamic model of market equilibrium with vertical product differentiation that enabled us to take into account the economic consequences of respondents' monthly income and species crop of three different communities. The objectives of the study are to identify the personal and socio-economic characteristics of farmers and determine the importance of biodiversity in the study area using Simpson's Index. The result showed that $52.50 \%$ were male, majority (32.50\%) were within the age range of 31 and 40 years old, $44.17 \%$ were married, $62.50 \%$ had household size of $6-10$, and majority (45.83\%) had secondary education while $46.67 \%$ had up to 20 years farming experience. In conclusion, the authors find that effective factors play an important role in explaining the support for biodiversity conservation, particularly when people do not have specific knowledge about species; while ecological-scientific considerations appear when people are well-informed.
\end{abstract}

\section{Keywords}

Economic, value, crop, productivity, biodiversity, consumers

Biodiversity denotes the wealth and variety of all living things. Naturalists have a long history of examining and classifying animals, plants, fungi, and other organisms, the term "biodiversity", meaning the total variability of life, dates only from the 1980s. Biodiversity is considered at three levels: species diversity, genetic diversity, and ecosystem diversity (Ammann 2004). The first category refers to the variety and abundance of species in a geographical area; the number of species is the simplest and most commonly used measure of biodiversity (Current,
Lutz, and Scher 1995). Despite the tendency to focus on species, relying on species and their numbers alone does not go far enough: Each species consists of subspecies, populations, and individuals. In fact, many

\footnotetext{
aLadoke Akintola University of Technology, Nigeria bFederal University of Technology, Nigeria

Correspondent Author:

Ayinde Alani Ezekiel, Department of Agricultural Economics, Faculty of Agricultural Sciences, Ladoke Akintola University of Technology, P.M.B 4000, Ogbomoso, Oyo State, Nigeria
} 
practical conservation decisions target subspecies and populations rather than species. The second and third categories of biodiversity, genetic and ecosystem diversity, have not garnered as much media coverage. Genetic diversity refers to variation between and within species, both among populations and among individuals within a population. Variation arises from mutations in genes, and natural selection of these characteristics is the primary mechanism of biological evolution. Ecosystem or systems diversity refers to the variation between communities and their associations with the physical environment (McNeely and Scherr 2003). Species have different functions within their communities; some can be substituted while others (key stone species) play determinant roles in the food web and cannot be removed without fundamentally altering the community itself. An example of a keystone species is the grey wolf. The cascading effects of the reintroduction of the grey wolf to Yellowstone demonstrate its disproportionate role in shaping the ecosystem. When wolves were absent, deer foraged in large numbers in riparian areas, removing vegetation and keeping areas open. The wolves' new presence has caused deer to avoid those areas where the risk being preyed upon is greatest. Consequently, with the re-growth of vegetation, riparian habitat for birds and beavers has increased both in quality and extent (Dollacker 2006). Several plants and trees that were previously overgrazed now flourish in spot that elk and deer avoid because of the presence of wolves. The new vegetation provides food for beaver and habitat for songbirds, and their populations have increased (Siikamaki 2008).

According to Singh (2000), biodiversity refers to the diversity of life in all its form and all its level of organization, not just plants, animals, and micro-organism species. At its most elemental level, biodiversity encompasses the varied assemblages of organic molecules that comprise the genetic basis of life. On the other end of the spectrum, there are biomes - the vast stretches of tundra, desert, forest, ocean, etc. For many people, the very questioning of the worth of biodiversity is illicit. They would argue that humankind has a moral obligation to conserve biodiversity, an obligation that comes with the fact that humans have the capability to destroy much of that biodiversity. Others find a religious support for such a vies, there is some stewardship responsibility on behalf of some deity. One problem with these moral views is that they often conflict with other moral views about, say, the right to earn a living, the right to have access to basic need such as food, cloth, shelter, and so on. If conserving biodiversity conflicts with those rights, then some "meta-ethical" principles are required for deciding which moral view should prevail (R. Prescott-Allen and C. Prescott-Allen 1988).

One aspect of the process of changing popular perceptions about biodiversity resources is to show that the sustainable use of biodiversity has positive economic value and that this economic value will often be higher than the alternative resources use which threatens biodiversity. Biodiversity or biological diversity refers to the variety of life forms on the planet - its plants, animals, microbes, and fungi, the genes that they contain and the ecosystems of which they are a part. The term is also often used to describe the diversity of organism within a particular area or range. This "local" biodiversity is of concern when human activity encroaches on habitat and pushes species out of the area or in some circumstances causes local or complete extinction of a species. All organisms rely on other life forms for their existence. Organisms using oxygen in respiration rely on plants for its production and food that comes from plants, animals, and fungi. Any change in number of one species will affect the lives of other species (Haffmans and Smolka 2008). Habitat degradation in the form of land clearing or introduction of foreign species is the main cause for losses in biodiversity; world agricultural trade depends on biodiversity. New varieties of livestock and crops are being bred continually from their wild "cousins" in order to stay ahead of pest and 
disease. These are being used to breed drought resistance, to boost nutritional content or to increase crop yields. Many common pharmaceuticals were first found in wild plants and animals and major searches are continuing around the world for new therapeutic compounds in wild species (Ammann 2004). Biodiversity is important to agriculture. All modern crop varieties were originally produced using land races developed by farmers around the world from wild plants over hundreds and thousands of years. Wild relatives of these crops still represent important reservoirs of genes that are essential for improving the crops or developing new strains to keep them from being overwhelmed by stresses such as changing climate or the evolution of new pest, parasites, and disease. Primitive populations of crops and their wild relatives are an important source and often the only source of pest and disease resistance worth many millions of dollars of adaptations to difficult environments and of other agronomical valuable characteristic such as the dwarf habit in rice and wheat which has revolutionized their cultivation and led to increased yields in many parts of the world from wild plants over hundreds and thousands of years (Aju and Ezebiekwe 2010). All agricultural activities are human-made interventions and involve the modification of natural ecosystems to provide for people's needs. Through land conversion to agriculture, the original ecosystem is replaced by an unceasing series of constantly occurring interventions such as tilling, sowing monocultures, harvesting, or crop rotation. Maintaining the right balance between habitat diversity and agricultural activities is therefore often a challenge. This challenge is already being addressed in many countries, through firmly embedding conversation objectives in land-use practices which enhance productivity and profitability and which can deliver mutual benefits to biodiversity and to productivity.

Humans take what they need from nature: food, raw materials, and medicine. Nature supplies the human race with clean water and provides us with services, such as the filter function of the ground or the recreational function of the ecosystems. The insidious loss of biological diversity becomes apparent later in technological societies, then in societies that live directly from nature where there is no possibility of compensating technologically for the losses resulting from damage to natural regulatory systems. For example, when fish stocks are exhausted due to over-fishing, the fishermen, their families, and whole village communities suffer from hunger. People in industrial nations only notice the dramatic change due to rising prices, but they have the choice of buying other food. With the concept of "ecosystem services", an attempt is being made to estimate the economic value of biological diversity. It has been calculated that globally, eco-systems provide important services to the value of about 26 trillion euros a year. The sum is far greater than the annual world gross social product. Despite this impressive figure, there can be no pure economic evaluation of natural systems. Biological diversity has an intrinsic value. However, as biological diversity cannot defend itself, attempts are being made by way of agreements, contracts, and action plans at international, European, and national level, to counteract the loss of biological diversity.

\section{PROBLEM STATEMENT}

Reduction in biological diversity is an inevitable outcome of economic pressures and technological innovations in the initial stages of agricultural development. As agriculture has developed, its effect on biological diversity has increased and the value of biological diversity is increasingly recognized. The effect of several economic and technical trends on agriculture suggests that incentives can be modified to reconcile continued profitability of the agricultural industry with sustaining the current biological diversity (Howitt 1995). A nation that integrates biodiversity conservation in a truly national 
programme of sustainable development is aimed at substantially reducing poverty, designing a secure future, and facilitating the growth of the Nigeria biodiversity for the benefit of Nigerian community and economy in line with the principles of ecological sustainability and social equity (CIA World Factbook 2010).

Therefore, the following research questions are fundamental to this study:

(1) What are the socio-economic characteristics of farmers?

(2) What is the importance of biological biodiversity?

(3) What is the relationship between respondent's personal/social-economic characteristic and crop productivity in the study area?

\section{OBJECTIVES OF THE STUDY}

The main objective of the study is to analyze the economic value of biological diversity on crop productivity in Ijebu Ode agricultural zone of Ogun State, Nigeria.

Specific objectives are:

(1) To identify the personal and socio-economic characteristics of farmers in the study area;

(2) To determine the importance of biodiversity in the study area;

(3) To determine the relationship between respondent's personal/social-economic characteristic and crops productivity in the study area.

\section{STUDY HYPOTHESIS}

$\mathrm{H}_{0}$ : There is no significant relationship between the socio-economic characteristics and crops productivity biodiversity in the study area.

\section{JUSTIFICATION OF THE STUDY}

In Nigeria, poverty is directly linked to biodiversity loss. This is because rural livelihoods depend almost entirely on biodiversity. In order to address biodiversity concerns, the problem of poverty must be addressed by providing alternative livelihood options to rural communities. Natural and man-made threats, socio-cultural problems as well as direct and indirect consequences of socio-economic development have contributed to the erosion of biodiversity at all levels. Nigeria, with a population of about 160 million people constitutes nearly a quarter of the total population of sub-Saharan Africa. A population growth rate of more than $3 \%$ and increasing poverty (especially in rural areas) has put severe demand on the country's natural resources, the institutional structures, and the resources available to manage them. There has been a general institutional weakness and lack of technical capacity to effectively tackle the nation's environmental issues, including threat to biological diversity. The loss of biodiversity is particularly apparent in the sector of agro-biodiversity. The international community relies more and more on fewer species of crops to provide for basic needs and within these species the genetic spectrum is becoming increasingly limited. Now experts have come up with the term "genetic erosion" for the loss of genetic diversity within species. This applies particularly to cultivated species such as wheat, rice, or maize. Of the thousands of different varieties that humans have cultivated in history, only a handful remains today. Agro-biodiversity also decreases with the falling number of cultivated field crops. Agricultural technology, the green revolution, the increasing market domination of a few multinational seed companies, the industrial processing of agricultural goods and global trade with its standardizations are driving forces in the standardization of cultivated crops and culture species.

\section{RESEARCH METHODOLOGY}

The study was carried out in Ijebu Ode zone of the 
OGADEP (Ogun State Agrcultural Development Programme). This is comprised of six local government areas. These are Isoyin, Ala, Ijebu-Igbo, Ago-Iwoye, Ijebu-Ife, Ibiade. The zone experiences both wet and dry season annually. The climate of the area favours arable crops production. The rainy season usually starts in March and lasts till November. The dry season is usually very hot except during harmattan period when it is cold and dry. According to Nigeria population census of 2006, majority of the populace combines subsistence farming with other occupation like trading, civil service, and handicraft. Ijebu Ode has an urban population of 154,032 and it lies between latitude $6^{\circ} 49^{\prime} 15^{\prime \prime} \mathrm{N}$ of the equator and between $3^{\circ} 55^{\prime} 15^{\prime} \mathrm{E}$ of the Greenwich meridian. Ijebu Ode has area landmass covering about $192 \mathrm{~km}^{2}$ and is located in the North Eastern part of Ogun State. The vegetation of Ijebu Ode is dominated by derived savannah and agriculture is the main occupation of the people. The people are predominant Yorubas.

\section{Population, Sampling Procedure and Sample Size}

The populations of the study were all crop farmers in Ijebu Ode agricultural zone of Ogun State. A multi-stage sampling technique was used to select the respondents. First stage was purposive selection of two (Ijebu-Ife, Ibiade) out of the six local government in the study area because of their rurality, 10 villages were randomly selected from the two local government. Then, a list of all the crop farmers in the chosen villages was obtained from the ADP (Agricultural Development Programme) zonal headquarters in Ijebu Ode; six crop farmers were then randomly selected from each of the selected 10 villages, which then gave a total of 120 respondents that was used for this study.

\section{Method of Data Collection}

A well-structured questionnaire was used in this study to obtain some relevant and adequate data from the respondents. This was administered through a careful in-depth interview.

\section{Method of Data Analysis}

Objective $i$. Descriptive analysis such as frequency counts, percentages, and mean was used to analyze the socio-economic characteristics of the respondents.

Objective ii. Descriptive analysis was used to determine the relationship between respondent's personal/social-economic characteristic and crop productivity in the study area. While Simpson's index was used to measure diversity, which takes into account both species richness, and an evenness of abundance among the species present. In essence, it measures the probability that two individuals selected from an area will belong to the species. The formula for calculating $D$ is presented as:

$$
\mathrm{D}=\frac{\sum \mathrm{n}_{i}\left(\mathrm{n}_{i}-1\right)}{\mathrm{N}(\mathrm{N}-1)}
$$

Where, $n_{i}=$ the total number of organisms of each individual species; $\mathrm{N}=$ the total number of organisms of all species. The value of $\mathrm{D}$ ranges from 0 to 1 . With this index, 0 represents infinite diversity and 1 represents no diversity. That is, the bigger the value, the lower the diversity.

\section{Regression Model Specification}

The model was expressed as: $\mathrm{Y}=\mathrm{b}_{0}+\mathrm{b}_{1} \mathrm{X}_{1}+\mu_{\mathrm{i}}$ where:

$\mathrm{Y}=$ crop yield/productivity measured in naira (dependent variable)

$\mathrm{b}_{0}=$ the intercept (parameter)

$b_{i}=$ regression coefficients (parameters) that explain the relationship of respondents' selected personal/socio-economic characteristics and crop yield/productivity explanatory variables $(i=1,2,3, \ldots$ n)

$\mu_{\mathrm{i}}=$ error term which accounts for unexplained factors. 


\section{RESULTS AND DISCUSSIONS}

This section discusses the socio-economic characteristics of the respondents.

\section{Distribution of Respondents by Sex}

Table 1 shows the distribution of the economic value of biodiversity crops productivity according to respondents' sex in the study area. It is observed that about $47.50 \%$ of the respondents in the study area are female while $52.50 \%$ are male. Economic value of biodiversity crop productivity in the study area is dominated by male farmers.

\section{Distribution of Respondents by Age}

It was observed from Table 2 that majority (32.50\%) of the respondents had their age between 31-40 years old in the study area, $25.83 \%$ of the respondents fall within the age range of 41-50 years old, $20.00 \%$ of the respondents fall within the age range of 51-60 years old while $15.00 \%$ of the respondents fall within the age range of 30 years old and below, and $6.67 \%$ of the respondents fall within the age range of 61 years old and above. The mean age of the respondent's farmers in the study area is 42.6 years old of age. This implies that the most of the farmers are very active and this will enhance their production activities in order to have economic value of biodiversity on crop productivity, also can adopt new technologies if exposed to them.

\section{Distribution of Respondents by Marital Status}

Results show that about $44.17 \%$ of the respondents were married in the study area while $29.17 \%$ of them were single and $13.33 \%$ each of the respondents were separated and widowed respectively (see Table 3 ). This result has implications on biodiversity on crop productivity in the study area. Married men and women are likely to be relatively stable and focused in carrying on their farming activities and the livelihood that they will have more people in the household who will contribute to labour input, hence, availability of more family labour.

\section{Distribution of Respondents by Household Size}

Table 9 shows the family members represent those being fed, clothed, and housed by a farmer. This can be an important indicator of farmer's productivity on the farm if the farmer has no other occupation apart from farming. The size of the household affects the amount of farm labour, determines the food and nutritional requirement of the household, and often affects household food security. Table 4 shows the distribution of respondents according to household size. Results in the table showed that majority $(62.50 \%)$ of the respondents in the study area have household sizes of about 6-10 members, followed by $35.00 \%$ of the respondents have household sizes of five members and below per family and about $2.50 \%$ of the respondents have more than 10 members per family. It is expected that the family members of a farm operator will contribute labour to farm work.

\section{Distribution of Respondents by Level of Education}

The level of education attained by a farmer is known to influence the adoption of innovation, better farming decision making including efficient use of inputs. The study showed that majority $(45.83 \%)$ of the biodiversity on crop productivity farmers had secondary education, $41.67 \%$ of the respondents had no formal education while $9.17 \%$ of them had tertiary education and $3.33 \%$ of them had primary education in the study area (see Table 5). The finding implies that literacy level is moderately high among the biodiversity on crop productivity farmers as expected in the study area.

\section{Distribution of Respondents by Years of Schooling}

Forty-one point six seven percent $(41.67 \%)$ of the respondents had no formal education, $3.33 \%$ of the respondents fall between 1-6 years, while $45.83 \%$ of the respondents fall between group of 7-12 years, and 
Table 1. Sex Distribution of Respondents

\begin{tabular}{lll}
\hline Sex & Frequency & Percentage (\%) \\
\hline Female & 57 & 47.50 \\
Male & 63 & 52.50 \\
Total & 120 & 100.0 \\
\hline
\end{tabular}

Note: Source: Field Survey Data, 2015.

Table 2. Age Distribution of Respondents

\begin{tabular}{lll}
\hline Age & Frequency & Percentage (\%) \\
\hline$\leq 30$ & 18 & 15.00 \\
$31-40$ & 39 & 32.50 \\
$41-50$ & 31 & 25.83 \\
$51-60$ & 24 & 20.00 \\
$\geq 61$ & 8 & 6.67 \\
Total & 120 & 100.0 \\
\hline
\end{tabular}

Note: Source: Field Survey Data, 2015; Mean age: 42.6.

Table 3. Distribution of Respondents by Marital Status

\begin{tabular}{lll}
\hline Marital status & Frequency & Percentage (\%) \\
\hline Married & 53 & 44.17 \\
Single & 35 & 29.17 \\
Separated & 16 & 13.33 \\
Widowed & 16 & 13.33 \\
Total & 120 & 100.0 \\
\hline
\end{tabular}

Note: Source: Field Survey Data, 2015.

Table 4. Distribution of Respondents According to Household Size

\begin{tabular}{lll}
\hline Household size & Frequency & Percentage (\%) \\
\hline$\leq 5$ & 42 & 35.00 \\
$6-10$ & 75 & 62.50 \\
$\geq 11$ & 3 & 2.50 \\
Total & 120 & 100.0 \\
\hline
\end{tabular}

Note: Source: Field Survey Data, 2015.

Table 5. Educational Level Distribution of Respondents

\begin{tabular}{lll}
\hline Educational level & Frequency & Percentage (\%) \\
\hline Non-formal & 50 & 41.67 \\
Primary & 4 & 3.33 \\
Secondary & 55 & 45.83 \\
Tertiary & 11 & 9.17 \\
Total & 120 & 100.0 \\
\hline
\end{tabular}

Note: Source: Field Survey Data, 2015. 
Table 6. Distribution of Respondent by Years of Schooling

\begin{tabular}{lll}
\hline Years of schooling & Frequency & Percentage (\%) \\
\hline No formal education & 50 & 41.67 \\
$1-6$ & 4 & 3.33 \\
$7-12$ & 55 & 45.83 \\
13 \& above & 11 & 9.17 \\
Total & 120 & 100.0 \\
\hline
\end{tabular}

Note: Source: Field Survey Data, 2015.

Table 7. Distribution of Respondents According to Their Religion

\begin{tabular}{lll}
\hline Religion & Frequency & Percentage (\%) \\
\hline Islam & 58 & 48.33 \\
Christians & 62 & 51.67 \\
Total & 120 & 100.0 \\
\hline
\end{tabular}

Note: Source: Field Survey Data, 2015.

Table 8. Distribution of Respondents According to Their Years of Farming Experience

\begin{tabular}{lll}
\hline Years & Frequency & Percentage (\%) \\
\hline$\leq 20$ & 64 & 53.33 \\
$20-40$ & 36 & 30.00 \\
$41 \&$ above & 20 & 16.67 \\
Total & 120 & 100.0 \\
\hline
\end{tabular}

Note: Source: Field Survey Data, 2015.

9.17\% of the respondents fall between group of 13 years and above (see Table 6). The means number of years spent in school was 6.75. This implies that the majority of the respondents are educated.

\section{Distribution of Respondents by Their Religion}

Table 7 revealed that $51.67 \%$ of the respondents were Christians, while $48.33 \%$ of the respondents were Muslims. This implies that most of the respondents were practicing religion in the study area.

\section{Distribution of the Respondents According to Their Farming Experience}

Table 8 shows that $53.33 \%$ of the respondents had experience of 20 years and below, $30.00 \%$ of the respondents had 20-40 years and the remaining $16.67 \%$ of the respondents had 41 years and above biodiversity farming experience. This implies that farmers who practiced biodiversity crop productivity were well experienced in the study area.

\section{Distribution of Respondents by Their Average Monthly Income}

The result shows that $40.83 \%$ of the respondents obtained average monthly income between N50,000-N70,000, $29.17 \%$ of the respondents cultivated average income between N71,000 and above, while $15.83 \%$ of them obtained between $\mathrm{N} 31,000-\mathrm{N} 50,000$ and $14.17 \%$ of them had between N30,000 and below (see Table 10).

\section{Distribution of Respondents by the Type of Agricultural Practices}

The results in Table 11 revealed that $51.67 \%$ of the respondents indicated traditional as an agricultural practice, $28.33 \%$ of them indicated conventional while 
Table 9. Distribution of Respondents by Household That Are Working on the Farm

\begin{tabular}{lll}
\hline Household & Frequency & Percentage (\%) \\
\hline$\leq 5$ & 113 & 94.17 \\
$6-10$ & 7 & 5.83 \\
Total & 120 & 100.0 \\
\hline
\end{tabular}

Note: Source: Field Survey Data, 2015.

Table 10. Distribution of Respondents by the Average Monthly Income

\begin{tabular}{lll}
\hline Monthly income $(\mathrm{N})$ & Frequency & Percentage (\%) \\
\hline$\leq 30,000$ & 17 & 14.17 \\
$31,000-50,000$ & 19 & 15.83 \\
$50,000-70,000$ & 49 & 40.83 \\
$\geq 71,000$ & 35 & 29.17 \\
Total & 120 & 100.0 \\
\hline
\end{tabular}

Note: Source: Field Survey Data, 2015.

Table 11. Distribution of Respondents by the Type of Agricultural Practices

\begin{tabular}{lll}
\hline Agricultural practices & Frequency & Percentage (\%) \\
\hline Traditional & 62 & 51.67 \\
Conventional & 34 & 28.33 \\
Ecological & 24 & 20.00 \\
Total & 120 & 100.0 \\
\hline
\end{tabular}

Note: Source: Field Survey Data, 2015.

$20.00 \%$ of the respondents indicated ecological as a type of agricultural practices in the study area.

\section{Crops Planted by Respondents}

Result shows that $13.33 \%$ of the respondents showed grains and legumes as type of food crops, $8.33 \%$ of them showed vegetables, $8.33 \%$ of them showed root and tubers, $35.83 \%$ of the respondents reported fruit crops as a type of food they were planting, while $25.83 \%$ of the respondents were planting cash crops and $8.33 \%$ of them indicated forage as a type of crops in the study area (see Table 12).

\section{Simpson's Index to Measure Biodiversity}

Table 13 showed three communities (Ijebu Igbo, Ago Iwoye, Ijebu Ife), each was made up of a total of 120 organisms and drawn from combinations of 10 species. From A to J, Community 1 has the highest diversity, it has the joint highest species richness (10) and each species has a similar relative abundance. Community 2 has the same species richness as community 1 , but is dominated by one species (A) so that the diversity of this community is lower than community 1 . Community 3 has a lower diversity than community 1 , due to its lower species richness.

\section{Actions Taken to Support the Conservation of Crop Wild Relative}

The result in Table 14 shows that $64.17 \%$ of the respondents have taken action to support the conservation of crop wild relative, while $35.83 \%$ of them have not taken any action to support the conservation of crop wild relative. 
Table 12. Distribution of Respondents by Crop Planted

\begin{tabular}{lll}
\hline Crop planted & Frequency & Percentage (\%) \\
\hline Grains and legumes & 16 & 13.33 \\
Root and tubers & 10 & 8.33 \\
Vegetables & 10 & 8.33 \\
Forage & 10 & 8.33 \\
Fruit crops & 43 & 35.83 \\
Cash crops & 31 & 25.83 \\
Total & 120 & 100.0 \\
\hline
\end{tabular}

Note: Source: Field Survey Data, 2015.

Table 13. Species Crop of Three Different Communities Using Simpson's Index Method

\begin{tabular}{llll}
\hline Species & Ijebu Igbo $\left(\mathrm{n}_{\mathrm{i}}\right)$ & Ago Iwoye $\left(\mathrm{n}_{\mathrm{i}}-1\right)$ & $\begin{array}{l}\text { Ijebu Ife }\left[\mathrm{n}_{\mathrm{i}}\left(\mathrm{n}_{\mathrm{i}}-1\right)\right] \\
\text { Community } 3\end{array}$ \\
\hline $\mathrm{A}=$ Maize & Community 1 & Community 2 & 35 \\
B = Legumes & 20 & 72 & 44 \\
$\mathrm{C}=$ Root and tubers & 11 & 6 & 41 \\
$\mathrm{D}=$ Vegetable & 10 & 13 & 0 \\
$\mathrm{E}=$ Forage crops & 8 & 3 & 0 \\
F = Fruit crops & 12 & 1 & 0 \\
G = Tree crops & 20 & 3 & 0 \\
H = Cash crops & 11 & 4 & 0 \\
I = Sucker crops & 10 & 3 & 0 \\
J = Beans & 9 & 2 & 0 \\
Total & 120 & 13 & 120 \\
\hline
\end{tabular}

Note: Source: Field Survey Data, 2015.

Table 14. Distribution of Respondents by Having Actions Been Taken to Support the Conservation of Crop Wild Relative

\begin{tabular}{lll}
\hline Action & Frequency & Percentage (\%) \\
\hline Yes & 77 & 64.17 \\
No & 43 & 35.83 \\
Total & 120 & 100.0 \\
\hline
\end{tabular}

Note: Source: Field Survey Data, 2015.

Table 15. Distribution of Respondents by Having Action to Support the Conservation of Crop-Associated Biodiversity and Wild Plants Used for Food

\begin{tabular}{lll}
\hline Action & Frequency & Percentage (\%) \\
\hline Yes & 85 & 70.83 \\
No & 35 & 29.17 \\
Total & 120 & 100.0 \\
\hline
\end{tabular}

Note: Source: Field Survey Data, 2015. 
Action Taken by the Government to Support the Conservation of Crop-Associated Biodiversity and Wild Plants Used for Food

Table 15 shows that $70.83 \%$ of the respondents have taken action to support the conservation of crop-associated biodiversity and wild plants used for food, while $29.17 \%$ of them did not take action to support the conservation of crop-associated biodiversity and wild plants used for food.

Actions Taken by the Respondents to Support or Encourage On-farm Maintenance of Traditional Varieties

Results revealed that $68.33 \%$ of the respondents have taken action to support or encourage on-farm maintenance of traditional varieties, while $31.67 \%$ of them did not take action to support or encourage on-farm maintenance of traditional varieties (see Table 16).

Action Taken by the Government to Support Crop Biodiversity

Sixteen point six seven percent $(16.67 \%)$ of the respondents reported policy as an action, $8.33 \%$ of them reported provision of incentive, $13.33 \%$ of them reported participatory plant breeding as an action, $18.33 \%$ of them reported small-scale seed production as an action, $20.83 \%$ of them reported development of markets as an action, while $9.17 \%$ of them reported farmer field schools as an action and $13.33 \%$ of them reported community seed banks as an action (see Table 17). This implies that majority of the respondents have different type of action in the study area.

\section{Distribution of Respondents by Weather Has Effect on Crop Productivity}

It was revealed that majority $(100.0 \%)$ of the respondents reported weather has effect on crop productivity (see Table 18). This implies that all the respondents are affected by weather condition on crop productivity in the study area.

\section{Effect of Weather Condition on Crop Productivity}

The results showed that $42.50 \%$ of the respondents reported heavy rain is a very severe effect of the weather condition on crop productivity, while $57.50 \%$ of them reported it is severe, $61.67 \%$ of the respondents reported droughts as a very severe effect while $38.33 \%$ of them indicated it as severe on the effect of crop productivity, $100.0 \%$ of the respondents reported floods as a very severe effect of weather conditions on crop productivity. Majority $(51.67 \%)$ of the respondents reported strong wings as very severe effect of weather conditions, while $30.83 \%$ of them indicated strong wings as severe and $17.50 \%$ of them reported it was not severe effect of weather conditions (see Table 19). This implies that majority of the respondents are severe to effect of weather conditions.

\section{CONCLUSIONS}

The result shows that $52.50 \%$ are male, majority $(32.50 \%)$ are within the age range of 31 and 40 years old, $44.17 \%$ are married, $62.50 \%$ have household size of 6-10, majority (45.83\%) have secondary education while 46.67 have up to 20 years farming experience.

In conclusion, the authors find that affective factors play an important role in explaining the support for biodiversity conservation, particularly when people do not have specific knowledge about species; while ecological-scientific considerations appear when people are well-informed.

This type of study offers the possibility to define and understand the underlying factors that determine the formation of human preferences toward wildlife and, therefore, reveals useful information for environmental management decision-making. 
Table 16. Distribution of Respondents by Having Actions Been Taken to Support or Encourage on Farm Maintenance of Traditional Varieties

\begin{tabular}{lll}
\hline Action & Frequency & Percentage (\%) \\
\hline Yes & 82 & 68.33 \\
No & 38 & 31.67 \\
Total & 120 & 100.0 \\
\hline
\end{tabular}

Note: Source: Field Survey Data, 2015.

Table 17. Distribution of Respondents According to the Type of Action Taking by the Government

\begin{tabular}{lll}
\hline Type of action & Frequency & Percentage (\%) \\
\hline Policy/Legislation & 20 & 16.67 \\
Provision of incentive & 10 & 8.33 \\
Development of markets & 25 & 20.83 \\
Participatory plant breeding & 16 & 13.33 \\
Small-scale seed production & 22 & 18.33 \\
Farmer field schools & 11 & 9.17 \\
Community seed banks & 16 & 13.33 \\
Total & 120 & 100.0 \\
\hline
\end{tabular}

Note: Source: Field Survey Data, 2015.

Table 18. Distribution of Respondents by Effect of Weather on Crops Productivity

\begin{tabular}{lll}
\hline Effect of weather & Frequency & Percentage (\%) \\
\hline Yes & 120 & 100.0 \\
Total & 120 & 100.0 \\
\hline
\end{tabular}

Note: Source: Field Survey Data, 2015.

Table 19. Distribution of Respondents on the Effect of Weather Condition on Crop Productivity

\begin{tabular}{llll}
\hline Weather & Very severe & Severe & Not severe \\
\hline Heavy rain & $51(42.50 \%)$ & $69(57.50 \%)$ & - \\
Drought & $74(61.67 \%)$ & $46(38.33 \%)$ & - \\
Floods & $120(100.0 \%)$ & - & $21(17.50 \%)$ \\
Strong wings & $62(51.67 \%)$ & $37(30.83 \%)$ & \\
\hline
\end{tabular}

\section{Recommendations}

(1) Society should be well informed and educated about social and ecological importance of food crops biodiversity;

(2) It is essential to raise people awareness about the value of biodiversity including less attractive species;

(3) Environmental NGOs (Non-Governmental
Organizations) "wildlife media"- television programmes and nature magazines - or environmental education programmes are the key drivers to change human values and attitudes toward biodiversity conservation.

\section{References}

Aju, P. C. and I. O. Ezebiekwe. 2010. "Understanding and Appreciating the Need for Biodiversity Conservation in 
Nigeria." Journal of Medicinal Plants Research 4(24): 2605-2608.

Ammann, K. 2004. "Biosafety in Agriculture: Is It Justified to Compare Directly With Natural Habitats? Balancing Productions of Promise and Peril." Ecological Society of America. Retrieved (http/www.botanischergarten.ch/ Frontiers-Ecology/Ammann-Forum-defl-pfd).

CIA World Factbook. 2010. Nigeria National Biodiversity Strategy and Action Plan. Retrieved December 30 (https://www.cbd.int/doc/world/ng/ng-nbsap-01-en.pdf).

Current, D. E., E. Lutz, and S. J. Scher. 1995. "Costs, Benefits and Farmer Adoption of Agro-forestry: Project Experience in Central America and the Caribbean." The World Bank Environment Paper Number 14. Washington, D.C.: World Bank.

Dollacker, A. 2006. Conserving Biodiversity Alongside Agricultural Profitability Through Integrated $R \& D$ Approaches and Responsible Use of Crop Protection Products. Retrieved (https://www.researchgate.net/ publication/242461174_Conserving_biodiversity_alongside _agricultural_profitability_through_integrated_RD_approac hes_and_responsible_use_of_crop_protec-_tion_products).

Haffmans, S. and S. Smolka. 2008. Biodiversity and Plant Protection Legislation. Hamburg, Germany: Pesticide Action Network Publication.

Howitt, R. 1995. "How Economic Incentives for Growers Can Benefit Biological Diversity: Peer-Reviewed Research Article." Clifornia Agricultural 49(6): 28-33.
McNeely, J. A. and S. J. Scherr. 2003. Ecoagriculture: Strategies to Feed the World and Save Wild Biodiversity. Washington, D.C.: Island Press.

Prescott-Allen, R. and C. Prescott-Allen. 1988. Genes From the Wild: Using Wild Genetic Resources for Food and Raw Materials. London: Eastscan Publications.

Siikamaki, J. H. 2008. "Perspectives on Sustainable Resources in America." Research Issue Magazine 168.

Singh, N. 2000. "Assigning Economic Value to Biodiversity." Millennium Issue 66(1). Retrieved (http://isebindia. com/2000/00-01-11.html).

\section{Bios}

Ayinde Alani Ezekiel, Ph.D., Department of Agricultural Economics, Faculty of Agricultural Sciences, Ladoke Akintola University of Technology, Nigeria; research field: environmental economics.

Igbekele Amos Ajibefun, Ph.D., professor, Department of Agricultural Economics and Resources Management, Federal University of Technology, Akure, Ondo State, Nigeria; research fields: environmental economics.

Taiwo Nuraeni Akinniran, Ph.D., Ladoke Akintola University of Technology, Nigeria; research fields: agricultural business and finance.

Folayimi Ogunwole-Olapade, Ph.D., Ladoke Akintola University of Technology, Nigeria; research field: production economics. 